\title{
The Influence of Principal Leadership, Work Discipline, and Achievement Motivation Towards the Performance of Senior High School Teachers
}

\author{
Ratri Romadhona * \\ Master Program of Education Management, Universitas Lambung Mangkurat, Banjarmasin 70123, \\ Indonesia
}

Article history:

Submission November 2019

Revised July 2020

Accepted September 2020

*Corresponding author:

E-mail:

ratri.romadhona@yahoo.com

\begin{abstract}
The purpose of this research is to describe and analyze the influence of the school principal's leadership, work discipline, achievement motivation, and teacher performance. This is a quantitative study with a simple proportionate sampling technique used to obtain data from 139 teachers from a total of 213 in 11 State Senior High Schools in Banjar District. The data were collected using a valid and reliable 1-4 Likert scale questionnaire and analyzed using descriptive statistics and path analysis with calculations using SPSS. The results showed that there was an influence of the principal's leadership on work discipline, achievement motivation, and teacher performance.
\end{abstract}

Keywords: principal leadership, work discipline, achievement motivation, performance

\section{Introduction}

The education quality obtained from good learning activity is a reflection of school achievement in preparing human resources to face global challenges associated with academics. Students' personality is determined by the teachers, therefore they need to possess a competent, responsible, skilled, and dedicated attitude. Furthermore, a high or low level of learning quality is influenced by teacher performance (Mulyani, 2012). The teacher acts as is a determinant of educational success through the performance at the institutional and instructional levels. Therefore, their quality of performance and professional abilities tend to influence the quality of educational outcomes. (Priansa, 2014).

According to Kompri (2016), human performance is determined by ability and motivation. Related to teacher performance, several factors influence it, such as quality, level of expertise, cultural and educational background, abilities and attitudes, interests and motivation, discipline, work ethic, job structure, expertise, and age/length of work. Teacher performance is defined as a condition that shows their ability to carry out their duties in schools and illustrates the existence of an act by developing the mandate and responsibility in educating, teaching, directing, and guiding students to achieve the expected level of maturity (Supardi, 2013). Furthermore, Supardi also stated that teachers' performance is the result of work, students' behavior, achievement in learning, and mastery of the competencies required in Law No. 14 of 2005 concerning Teachers and Lecturers.

Performance appraisal is a method for comparing various jobs using formal and systematic procedures to decide the order of their levels by determining their position and ratio (Sinambela, 2012). Teacher capabilities and competencies are measured and identified using their Performance Assessment. This system is based on the Minister of National Education Regulation Number 16 the Year

\section{How to cite:}

Romadhona, R. (2020). The influence of principal leadership, work discipline, and achievement motivation towards the performance of Senior High School Teachers. Journal of K6, Education, and Management, 3 (1), 82 - 89. doi: 
2007 regarding Academic Qualification Standards and Teacher Competencies. 4 competencies are under these regulations, namely pedagogic, personality, social, and professional, which are then more clearly broken down into 14 sub-groups as formulated by the National Education Standardization Board and regulated in book 2 guidelines for implementing Teacher Performance Assessment.

The factor influencing work performance is discipline, which reflects responsibility in fostering morale and achieving set goals. Low discipline is followed by lower job responsibilities (Hasibuan, 2013). Sinambela (2012) stated that discipline is the ability to work regularly, diligently, and continuously according to established rules.

The teacher's work discipline is also interpreted as their actions in carrying out learning tasks on students based on earnest and full effort following applicable regulations. The elements of work discipline as follows: (1) loyalty, (2) obedience, (3) responsibilities, (4) personality, and (5) performance (Saud, 2012). Principals as educational leaders in schools, need to be able to generate self-discipline in their subordinates. This ability is related to developing patterns and standards of behavior and implementing regulations to enforce employee discipline. It aims to instill cooperation and respect for authority and people. Discipline is also one of the factors needed to carry out organizational activities. According to Hasibuan (2013), the indicators influencing the level of employee discipline in an organization according are (1) goals and abilities, (2) role models and leaders, (3) rewards/salaries and welfare, (4) fairness, (5) inherent supervision, (6) sanctions/penalties, (7) assertiveness, and (8) humanitarian relations. These factors show the important role of leaders in applying disciplines. Initially, it was difficult to enforce discipline in the work environment. However, with the application of consistent sanctions which are supported by the zeal and effort from all factors, organizations are capable of achieving a positive culture. According to Barnawi and Arifin (2012), there are five aspects of teacher's work discipline towards (1) official assignments, with indicators of obeying school rules, preparing complete teaching curriculum, and in carrying out basic tasks, (2) proper utilization of time, (3) work atmosphere, by utilizing the school environment, establishing a good relationship, as well as maintaining a balance between rights and obligations, (4) serving students, parents, and the surrounding community, and (5) attitudes and behavior, with indicators of paying attention to students'self-esteem.

Another factor that influences performance is motivation. According to Azwar (2015), motivation is stimulation, encouragement, or power generation owned by a person or group willing to carry out an activity to achieve set goals. This usually encourages the desire to fulfill organizational needs. One of the motivations needed by teachers to support their performance is an achievement that is self-driven in overcoming all challenges and obstacles (Usman, 2013). David McClelland first stated the achievement motivation theory, which emphasized that a person's needs are formed through a learning process and are obtained in interaction with the environment (Ardana et al., 2012). This theory is also known as the "Three Needs."

According to McClelland (2015), the needs theory that determines human behavior in organizations is achievement, power, and affiliation. People with high achievement motives are characterized by (1) being brave to take risks, superior, and wanting to achieve the best, (2) carrying out tasks according to their competence, (3) work hard and take pride in the results achieved, and (4) pay attention to the future. Those with high-power motives are characterized by (1) the desire to influence groups, and (2) the ability to control others. While those with high friendliness motives are characterized by (1) feedback on tasks, (2) preference to cooperative situations, and are more effective when working with others. Educational leadership plays an important role in directing and mobilizing organizations to achieve the expected goals (Kurniadin \& Machali, 2016). According to Usman (2013), principals need to be able to carry out the function of mobilization by fostering cooperation, directing, and encouraging the 
work passion of teachers and employees. Therefore, they need to understand human factors and behavior.

Leaders need to collaborate with people both individually and in groups whose purpose is to discuss and solve problems related to the quality of school education. The main attention or priority in the leadership activities of the principal is to make improvements and improve the quality of learning (Suparlan, 2015). Wahjosumidjo (2013) stated that the principal's leadership are characters, personal behavior, influence on others, interaction patterns of cooperative relations, administrative positions, and other perceptions of legitimacy. The principal's leadership is measured through indicators of openness, attention to subordinates, interaction, and decision-makers.

In a previous study conducted a study of leadership. In general, the results show that leadership, work discipline, and achievement motivation have positive effects on performance.The research conducted by Hidayatullaeli (2016), stated that there is a positive and significant influence between principal leadership and the achievement motivation of teacher performance. Better leadership leads to higher teacher's performance. Furthermore, the better the achievement motivation factor, the higher the teacher motivation.

According to Hersona and Sidharta (2017), the functions of leadership, motivation, and work discipline have a significant effect both partially and simultaneously on performance. This means that by developing leadership functions, employee motivation and work discipline tend to improve performance. Nafiqoh's research (2017) results showed a very high influence between the principal's leadership on teaching performance, and achievement. In many studies, the majority of research results described a positive and significant relationship between variables. This research uses four variables, namely principal leadership, work discipline, achievement motivation, and teacher performance. These factors and conditions have an influence on principals' leadership in State Senior High Schools in Banjar District. Therefore, to overcome these problems, the variables of teacher performance, work discipline, achievement motivation, and principal school leadership were utilized.

\section{Material and Methods}

This research uses a quantitative approach with descriptive methods, as shown in Figure 1.

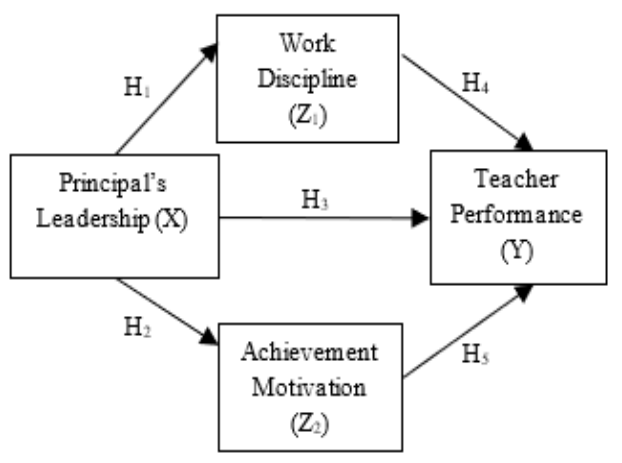

Figure 1. Research model

Data were collected from a questionnaire with four scale model by selecting the best answer that suits the actual conditions. A total of three questionnaires were used in this research, namely the principal's leadership, work discipline, and achievement motivation. While the teacher performance variables were obtained from Teacher Performance Assessment data results in 2018.

Following the research model, path analysis was used to answer seven research hypotheses with an influence of H1: school leadership on work discipline, H2: school leadership on achievement motivation, H3: school leadership on teacher performance, H4: work discipline towards teacher performance, H5: achievement motivation towards teacher performance, H6: principal's leadership on teacher performance through work discipline, H7: principal's leadership on teacher performance through achievement motivation. 
R Romadhona., 2020 / The influence of principal leadership, work discipline, and achievement motivation the performance

Table 1: Population and research samples

\begin{tabular}{ccccc}
\hline No & School & $\begin{array}{c}\text { Total Number of } \\
\text { Teacher }\end{array}$ & Calculation & Total of Sample Results \\
\hline 1. & SMAN 1 Martapura & 39 & $(39 / 213) \times 139$ & 25 \\
\hline 2. & SMAN 2 Martapura & 24 & $(24 / 213) \times 139$ & 16 \\
\hline 3. & SMAN 1 Gambut & 30 & $(30 / 213) \times 139$ & 20 \\
\hline 4. & SMAN Banua & 16 & $(16 / 213) \times 139$ & 10 \\
\hline 5. & SMAN 1 Karang Intan & 17 & $(17 / 213) \times 139$ & 11 \\
\hline 6. & SMAN 1 Sungai Tabuk & 25 & $(25 / 213) \times 139$ & 16 \\
\hline 7. & SMAN 1 Mataraman & 22 & $(22 / 213) \times 139$ & 14 \\
\hline 8. & SMAN Aluh-Aluh & 17 & $(17 / 213) \times 139$ & 11 \\
\hline 9. & SMAN 1 Pengaron & 10 & $(10 / 213) \times 139$ & 7 \\
\hline 10. & SMAN 1 Beruntung Baru & 12 & $(12 / 213) \times 139$ & 8 \\
\hline 11. & SMAN 1 Paramasan & 1 & $(1 / 213) \times 139$ & 1 \\
\hline
\end{tabular}

The results of the descriptive statistical analysis of respondents on the research variables on school principal leadership, work discipline, achievement motivation, and teacher performance are shown in table 2 .

The classical assumption test results include residual normality of principals' leadership data, work discipline, achievement motivation, and teacher performance. The normal probability plot of regression and standardized residual, where the data distribution points which were normally distributed around the diagonal lines. Heteroscedasticity test results using scatterplot regression studentized residual diagrams, with its random spread both above and below the number 0 on the Y-axis.
The results of the multicollinearity test showed that the VIF value of each independent variable is below 10. This means that the regression model is free from multicollinearity cases. Furthermore, the linearity autocorrelation test results showed a Durbin-Watson (DW) value of 1.949, which is located between 1.55-2.46, without autocorrelation in the regression model of the influenced principal's leadership with work discipline, achievement motivation, and teacher performance. The testing results of the analysis requirements have been fulfilled with the next step used to interpret path analysis with a summary of the results shown in Tables 3,4 , and 5 .

Table 2. Descriptive Research Variable Table

\begin{tabular}{ccccc}
\hline \multirow{2}{*}{ Variable } & \multicolumn{3}{c}{ Descriptive } \\
\cline { 2 - 5 } & Mean & Minimum & Maximum & Std. Deviation \\
\hline Teacher's Performance & 3.37 & 3.25 & 3.56 & 3.60630 \\
\hline Work discipline & 3.24 & 3.13 & 3.42 & 18.56145 \\
\hline $\begin{array}{c}\text { Achievement Motiva- } \\
\text { tion }\end{array}$ & 3.11 & 2.95 & 3.35 & 9.66300 \\
\hline Principal's Leadership & 2.91 & 2.68 & 3.05 & 10.84452 \\
\hline
\end{tabular}

Table 3. Summary of Path Analysis Results

\begin{tabular}{cccccc}
\hline \multirow{2}{*}{ Variable } & \multicolumn{5}{c}{ Substructural 1 } \\
\cline { 2 - 6 } & Path coefficient & $\boldsymbol{T}$ & Sig & $\boldsymbol{R}^{\mathbf{2}}$ & $\boldsymbol{F}$ \\
\hline Principal's Leadership & 0.442 & 5.772 & 0.000 & 0.196 & 33.317 \\
\hline
\end{tabular}

Dependent variable: Work Discipline 
Table 4. Summary of Path Analysis Results

\begin{tabular}{cccccc}
\hline \multirow{2}{*}{ Variable } & \multicolumn{5}{c}{ Substructural 2 } \\
\cline { 2 - 6 } & Path coefficient & $\boldsymbol{T}$ & Sig & $\boldsymbol{R}^{\mathbf{2}}$ & $\boldsymbol{F}$ \\
\hline Principal's Leadership & 0.487 & 6.518 & 0.000 & 0.237 & 42.484 \\
\hline
\end{tabular}

Dependent variable: Achievement Motivation

Table 5. Summary of Path Analysis Results

\begin{tabular}{cccccc}
\hline \multirow{2}{*}{ Variabel } & \multicolumn{5}{c}{ Substructure 3 } \\
\cline { 2 - 6 } & Path Coefficient & $\boldsymbol{T}$ & Sig & $\boldsymbol{R}^{\mathbf{2}}$ & $\boldsymbol{F}$ \\
\hline Principal's Leadership & 0.187 & 2.074 & 0.040 & 0.217 & 12.382 \\
\hline Work discipline & 0.197 & 2.133 & 0.035 & 0.217 & 12.382 \\
\hline $\begin{array}{c}\text { Achievement Motiva- } \\
\text { tion }\end{array}$ & 0.190 & 2.009 & 0.047 & 0.217 & 12.382 \\
\hline
\end{tabular}

Dependent variable: Teacher's Performance

Table 6. Summary of Direct Hypothesis Testing Decisions

\begin{tabular}{lccc}
\hline \multicolumn{1}{c}{ Hypothesis } & $\mathbf{H}_{\mathbf{1}} \mathbf{H}_{2} \mathbf{H}_{3} \mathbf{H}_{4}$ and $\mathbf{H}_{5}$ & Sig & Decisions \\
\cline { 2 - 4 } $\begin{array}{l}\text { H1: There is a direct influence on the principal's leadership towards work } \\
\text { discipline }\end{array}$ & 0.000 & Accepted \\
\hline H2: The principal's leadership influences towards achievement motivation & 0.000 & Accepted \\
\hline H3: The principal's leadership influences towards the teacher's performance & 0.040 & Accepted \\
\hline H4: The work discipline influences towards teacher performance & 0.035 & Accepted \\
\hline H5: The achievement motivation influences towards teacher performance & 0.047 & Accepted \\
\hline
\end{tabular}

Table 7. Summary of Indirect Hypothesis Testing Decisions

\begin{tabular}{lccc}
\hline \multicolumn{1}{c}{ Hypothesis } & $\mathrm{H}_{6}$ and $\mathrm{H}_{\mathbf{7}}$ & & \\
\cline { 2 - 4 } & $\begin{array}{c}\text { Path coeffi- } \\
\text { cient }\end{array}$ & Decisions \\
\hline $\begin{array}{l}\text { H6: There is an indirect influence on the principal's leadership towards } \\
\text { work discipline }\end{array}$ & 0.274 & Accepted \\
\hline $\begin{array}{l}\text { H7: There is an indirect influence on the principal's leadership towards } \\
\text { achievement motivation }\end{array}$ & 0.280 & Accepted \\
\hline
\end{tabular}

The path analysis results in Tables 3 and 4 are used to answer the five research hypotheses that have been formulated and discussed in Tables 6 and 7. Furthermore, table 6 is a summary of hypothesis $\mathrm{H}, \mathrm{H}_{2}, \mathrm{H}_{3}, \mathrm{H}_{4}$, and $\mathrm{H}_{5}$, which are accepted when the significance value is less than 0.05. Table 7 summarizes the decision of testing hypotheses $\mathrm{H}_{6}$ and $\mathrm{H}_{7}$. When the coefficient on indirect relationships is greater than the direct, the significance is also less than 0.05, and then the hypothesis is accepted. Following Tables 6 and 7, the results of the analysis found a relationship between variables, which are explained as follows.
There is an influence between the principal's leadership towards the teacher's work discipline

The results of this research prove that there is an influence between the principal's leadership and the teacher's work discipline, as seen from the path coefficient value of 0.442 . This is in line with (Rifa'i, 2018) research which stated that the principal is responsible for the teachers' ability to work with good discipline and on time. The results of this research are supported by (Singodimedjo, 2002) stated that exemplary courage in taking action and supervision from the principal are factors that influence teacher discipline. 
There is an influence between the principal's leadership towards teacher achievement motivation.

This is seen from the path coefficient value of 0.487 . It makes the teacher active, creative, accepts criticisms, and develop themselves. This is supported by the opinion of John and Harding (2011) that school principals need to be able to improve or refine the motivation of their subordinates or teachers. The results of this research are in line with Zendri and Masdupi (2014), which stated that leadership had a significant positive effect on achievement motivation. Besides, Ndapaloka et al. (2016) found similar results that there is a direct influence of leadership on achievement motivation.

\section{There is an influence between the principal leadership towards teacher performance}

This is seen in the path coefficient of 0.187. It is proven that the principal as a leader tends to influence the teacher in carrying out their tasks and functions, thereby improving performance. The results of this research are in line with Hartono and Zubaidah (2018), which stated that the quality of teacher performance is improved through the development of principals' leadership. (Satriadi, 2016) also stated that there is a strong relationship or correlation between the leadership variables of the principal and teacher performance.

\section{There is an influence of work discipline to- wards teacher performance}

The results of this research prove that there is an influence of work discipline on teacher performance with a path coefficient of 0.197 . It is proven that teachers with a good attitude and behavior in obeying all the rules tend to carry out the tasks with full awareness. Furthermore, Wukir (2013) stated that good discipline builds professional performance. The results of the research are in line with Wahyudi (2012) found that there was a simultaneous influence of work discipline on teacher performance, which can improve teacher performance. The stated that work discipline has a very positive and significant effect on teacher performance.

\section{There is an influence of achievement motiva- tion towards teacher performance}

This is seen in a path coefficient of 0.190 , which proves that achievement motivation in a teacher influences carrying out work in accordance with their skills and abilities. This is supported by Usman (2013), one of the characteristics of people with high achievement motives, which is carried out following their competencies. The results of this research were reinforced by Liana (2012), which stated that there is a significant influence between teacher achievement motivation and performance.

\section{There is an influence of principal leadership towards teacher performance through teacher work discipline}

This is seen in an indirect path coefficient of 0.274 , which is greater than the direct path of work discipline on teacher performance or the principal's leadership. It is proven that a school principal that acts decisively on rules and regulations encourages teachers to implement regulations without coercion, which negatively impacts on their performance. This is supported by Wirawan (2016), which stated that performance is a result of several factors, including leadership and work discipline. This research is in line with Purwoko (2018) that there is a positive and significant influence of school principals' leadership and teacher work discipline on performance.

There is an influence of principal leadership towards teacher performance through teacher achievement motivation

There is an influence of school principal leadership on teacher performance through achievement motivation with an indirect path coefficient of 0.280 . This is greater than the direct path coefficient of achievement motivation on teacher performance or the principal's leadership. It is proven that achievement motivation arises when there are support and encouragement from the leadership. Supardi (2013) stated that mental attitude, including motivation and leadership management, influences performance. The results of the research are in line with 
Ndapaloka et al. (2016) found that there was an indirect effect of school principal leadership on teacher performance through achievement motivation.

\section{Conclusion and Recommendation}

The conclusions obtained from all the results of the analysis in the research that has been conducted that the leadership of the school gives the influence to work discipline, achievement motivation, and teacher performance. Furthermore, work discipline influences teacher performance, achievement motivation influences teacher performance, and leadership of school principals also influences teacher performance through work discipline, and achievement motivation.

Besides, based on these conclusions, it is recommended that teachers improve discipline as well as social and professional competence. Also, school principals need to pay more attention to subordinates to create harmonious relationships that have an impact on improving teacher performance. While policymakers need to provide rewards for outstanding teachers and sanctions for those lacking discipline in accordance with the level of violations.

\section{Acknowledgment}

The authors are grateful to the reviewers and the Editorial Journal of K6, Education, and Management for providing an opportunity to publish the results of this research, and all those that assisted from the beginning till the publication of this article. May Allah SWT bless you all, Amin.

\section{References}

Ardana, I.K., Mujiati, N.W., \& Utama, I.W.M. (2012). Manajemen sumber daya manusia. Yogyakarta: Graha Ilmu.

Azwar, S. (2015). Sikap manusia: Teori dan pengukurannya. Yogyakarta: Pustaka Pelajar.

Barnawi., \& Arifin, M. (2012). Kinerja guru profesional: Instrumen pembinaan, peningkatan \& penilaian. Jogjakarta: Ar-Ruzz Media.

Hartono, B.D., \& Zubaidah. (2017). The influence of leadership, organizational culture, and work discipline on teacher performance regarding work motivation as intervening variable (a Case study of yayasan pendidikan pondok pesantren al kholidin). International Journal of Economics, Business and Management Research, 1(1), 69-95.

Hasibuan, M. S. (2013). Manajemen sumber daya manusia. Jakarta: Bumi Aksara.

Hersona, S., \& Sidharta, I. (2017). Influence of leadership function, motivation, and work discipline on employees' performance. Journal of Applied Management. 15 (3), 528-537. doi: http://dx.doi.org/10.21776/ub.jam.2017.015.03.18

Hidayatullaeli, A.M. (2016). Pengaruh kepemimpinan kepala sekolah dan motivasi berprestasi terhadap kinerja guru sd negeri gugus sari kelapa dan wiyata mandala kecamatan cilongok (Thesis). Retrieved from: https://lib.unnes.ac.id/28920/1/1401412048

John, D.T., \& Harding, H. A. (2011). Manajemen operasi: Untuk meraih keunggulan kompetitif. Jakarta: PPM.

Kompri. (2016). Manajemen pendidikan: Komponen-komponen elementer kemajuan sekolah. Yogyakarta: Ar-Ruzz Media.

Kurniadin, D., \& Machali, I. (2016). Manajemen pendidikan: Konsep \& prinsip pengelolaan dalam pendidikan. Yogyakarta: Ar-Ruzz Media.

Liana, Y. (2012). Iklim organisasi dan motivasi berprestasi terhadap kepuasan kerja dan kinerja guru. Jurnal Manajemen dan Akuntansi, 2(1), 15-30. Retrieved from http://publishing-widyagama.ac.id/ejournal-v2/index.php/jma/article/view/285/280

McClelland, D. (2015). The achievement motive (1953 ed.). Eastford: Martino Publishing.

Mulyani, A. (2012). Pengaruh kinerja kepala sekolah dan kinerja guru terhadap mutu pembelajaran pada SMK se-kabupaten purwakarta. Jurnal Administrasi Pendidikan, 1(14), 86-92

Nafiqoh, H. (2017). Pengaruh kepemimpinan kepala sekolah dan motivasi berprestasi terhadap kinerja guru pendidikan anak usia dini (Studi deskriptif analitik pada kepala sekolah dan guru taman kanak-kanak di kota bandung tahun pelajaran 2014/2015). Tunas Siliwangi, 1(3), 57-55.

Ndapaloka, V., Hardyanto, W., \& Prihatin, T. (2016). Pengaruh supervisi akademik pengawas dan kepemimpinan kepala sekolah melalui motivasi berprestasi sebagai mediasi terhadap kinerja guru SMK negeri kabupaten ende. Educational Management, 5(1), 42-54.

Priansa, D.J. (2014). Kinerja dan profesionalisme guru. Bandung: Alfabeta.

Purwoko, S. (2018). Pengaruh kepemimpinan kepala sekolah, komitmen guru, disiplin kerja guru, dan budaya sekolah terhadap kinerja guru SMK. Jurnal Akuntabilitas Manajemen Pendidikan, 2(6), 149-162. doi:http://dx.doi.org/10.21831/amp.v6i2.8467.

Rifa'i, M. (2018). Pengaruh kepemimpinan kepala sekolah terhadap disiplin kerja guru sekolah dasar negeri 060794 
kecamatan medan area. Jurnal Manajemen Pendidikan dan Keislaman, 7(1), 42-50.

Satriadi. (2016). Pengaruh kepemimpinan kepala sekolah terhadap kinerja guru. Jurnal Benefit, 1(3), 123-133. doi:http://dx.doi.org/10.22216/jbe.v1i3.874

Saud, U.S. (2012). Pengembangan profesi guru. Bandung: Alfabeta.

Sinambela, L.P. (2012). Kinerja pegawai: Teori pengukuran dan implikasi. Yogyakarta: Graha Ilmu.

Singodimedjo, M. (2002). Manajemen sumber daya manusia. Surabaya: SMMAS.

Supardi. (2013). Kinerja guru. Jakarta: Rajawali Pers.

Suparlan. (2015). Menjadi guru efektif. Yogyakarta: Hikayat Publishing.
Usman, H. (2013). Manajemen: Teori, praktik, dan riset pendidikan. Jakarta: Bumi Aksara.

Wahjosumidjo. (2013). Kepemimpinan kepala sekolah. Jakarta: Remaja Rosdakarya.

Wahyudi, A. (2012). Pengaruh disiplin kerja, motivasi kerja, dan supervisi kepala sekolah terhadap kinerja guru. Economic Education Analysis Journal, 2(1), 1-8.

Wirawan. (2016). Evaluasi kinerja sumber daya manusia: Teori, aplikasi, dan penelitian. Jakarta: Salemba Empat.

Wukir. (2013). Manajemen sumber daya manusia dalam organisasi sekolah. Yogyakarta: Multi Pressindo.

Zendri., \& Masdupi, E. (2014). Pengaruh kepemimpinan, motivasi berprestasi dan kepuasan kerja terhadap kinerja pegawai badan penanggulangan bencana daerah kabupaten tanah datar. Jurnal Riset Manajemen Bisnis dan Publik, 1(2): 1-9. 